\title{
Study of Service Ability in Sepaktakraw (Effect Leg Muscle Power, Flexibelity and Self Confidence of Service Abilities)
}

\author{
Didin Tohidin, Endang Sepdanius*, Ahmad Arhadni Putra \\ Sport Science Study Program, Faculty of Sport Science, Universitas Negeri Padang, Indonesia
}

Received April 22, 2021; Revised July 19, 2021; Accepted July 29, 2021

\section{Cite This Paper in the following Citation Styles}

(a): [1] Didin Tohidin, Endang Sepdanius, Ahmad Arhadni Putra , "Study of Service Ability in Sepaktakraw (Effect Leg Muscle Power, Flexibelity and Self Confidence of Service Abilities)," International Journal of Human Movement and Sports Sciences, Vol. 9, No. 5, pp. 905 - 911, 2021. DOI: 10.13189/saj.2021.090511.

(b): Didin Tohidin, Endang Sepdanius, Ahmad Arhadni Putra (2021). Study of Service Ability in Sepaktakraw (Effect Leg Muscle Power, Flexibelity and Self Confidence of Service Abilities). International Journal of Human Movement and Sports Sciences, 9(5), 905 - 911. DOI: 10.13189/saj.2021.090511.

Copyright $\mathrm{O} 2021$ by authors, all rights reserved. Authors agree that this article remains permanently open access under the terms of the Creative Commons Attribution License 4.0 International License

\begin{abstract}
Service is the basic technique in the Sepaktakraw game. Serve is the initial attack to earn points. To be successful in the implementation of this special technique in Sepaktakraw, a good physical condition and good psychological condition are needed. To see the effect of physical conditions and psychological conditions that have a direct and indirect effect on the ability to serve Sepaktakraw, a research on the ability to serve Sepaktakraw was carried out. The research method used is a quantitative method using a Path Analysis approach. The study population was the athletes of West Sumatra Sepaktakraw. The sampling technique was carried out by means of positive sampling and obtained 40 sepaktakraw athletes. The data obtained will be processed using data analysis techniques with the Path Analysis approach. The research instrument used are vertical jump for leg muscle explosive power, stand and rich test for flexibility, self-confidence questioner for self-confidence and service ability test instrument for service skill. The results showed that leg muscle explosive power has a direct effect on serviceability by $10.1 \%$, flexibility has a direct effect on serviceability amounting to $39.81 \%$, and self-confidence has a direct effect on serviceability amounting to $6.81 \%$. Influence of explosive power through self-confidence on the service ability of sepaktakraw athletes is $19.2 \%$. Influence of flexibility on serviceability through confidence in sepaktakraw athletes is $18.1 \%$, and the influence of the variable explosive power, flexibility and
\end{abstract}

self-confidence had an effect on serviceability amounting to $49.6 \%$. However, the remaining $50.4 \%$ is influenced by other factors.

Keywords Leg Muscle Power, Flexibility, Self-confidence, Service Abilities

\section{Introduction}

Education and development of community track sports achievements is based on the development of sports for all people that last a lifetime (SKN: 13). Efforts to breed and foster achievement sports are carried out centrally under the coordination of each sports branch organization together with the community. One of the sports that needs guidance is the sport of sepaktakraw. In an effort to improve the quality of motion and increase the athlete's performance in the sepaktakraw game, technique is very closely related to the ability to move, physical condition, tactics and mentality[1][2].

The success or failure of skills development depends on the age, anthropometry and physical abilities of the athletes. sepaktakraw game is a sport that requires physical and anthropometric conditions including height, because having a high body posture will make it easier to perform special techniques such as doing hard and sharp 
service[3]. The distance between feet and the ball is greatly influenced by height and flexibility of the feet. Flexibility plays an important role in implementing movement skills to develop service speed[4]. Then, in order to make the ball go faster, leg muscle explosive power is also needed[5].

Simultaneously, serving also involves other aspects such as confidence and the athlete's visual predictive ability in interpreting the serve against the ball[6]. Utilizing the confidence of a sepaktakraw athlete is an added value in offering service to initiate attack patterns. To see the importance of aspects of physical ability (explosive power and flexibility) and psychological aspects (self-confidence), it is necessary to conduct research to see the effect on the ability to serve sepaktakraw.

The problem to be investigated is whether there is a direct effect of 1) flexibility on serviceability, 2) explosive power on serviceability, 3) confidence in serviceability. 4) flexibility towards serviceability through self-confidence, 6) explosive power towards service ability through self-confidence, 7) whether flexibility, leg muscle explosive power, self-confidence have a simultaneous effect on service ability.

This study aims to reveal the magnitude of the influence: 1) Flexibility on serviceability, 2) Explosive power of leg muscles on serviceability, 3) Self-confidence in serviceability, 4) Flexibility towards serviceability through self-confidence, 6) Explosive power of leg muscles towards serviceability. Service ability through self-confidence in the sepaktakraw game, 7) Flexibility, leg muscle explosive power, and confidence have a simultaneous effect on service ability.

\section{Materials and Methods}

The method used in this research is a quantitative method using the path analysis approach, which uses structural equations that look at the causality of the dimensions of the effects of leg muscle explosive power (X1), flexibility (X2), self-confidence (X3). serviceability (Y) to see whether or not the influence of the causal variable on the effect variable is through the use of the Path Analysis method. The data obtained will be analyzed to find the interrelationship between the variables.

The study population was the athletes of West Sumatera sepaktakraw. The sampling technique was carried out by means of positive sampling with the criteria that they had attended a minimum of provincial sports week and obtained 42 sepaktakraw athlete. The athletes are males with an average age of 19 years and they are able to smash.

To get the data on leg muscle explosive power, this research uses a vertical jump test instrument. Data is obtained by subtracting the highest jump result in three jumps with the initial achievement. For flexibility, the stand and rich test is used. The test participant stands on the instrument box then slowly bends down and presses the pedal on the instrument to the limit of the test participant's ability and is finally held for a few seconds. The end of the pedal will show how many bends the athlete has done. This activity is carried out in three repetitions and the best number is taken. Self-confidence data was taken using a questionnaire which was developed based on two indicators, namely intrinsic and extrinsic. While the service ability was developed by Sepdanius based on two indicators, namely the position of the ball falling and the height of the foot contact with the ball. The research instrument used is shown in the following table 1 :

Table 1. Variables and research instruments

\begin{tabular}{|c|c|c|}
\hline No. & Variable & Instrument \\
\hline 1 & $\begin{array}{c}\text { Leg Muscles Explosive } \\
\text { Power }\end{array}$ & Vertical Jump \\
\hline 2 & Flexibility & Stand and rich test \\
\hline 3 & Confidence & Self-Confidence Questioner \\
\hline 4 & serviceability & $\begin{array}{c}\text { Serviceability test } \\
\text { instrument }\end{array}$ \\
\hline
\end{tabular}

\section{Results and Discussion}

\subsection{Result}

The normality test was carried out on the variables using the Lilliefors test with a significance level $\alpha=0.05$. The test criterion is that $\mathrm{H} 0$ is rejected if $\mathrm{L} 0$ obtained from the observational data exceeds $\mathrm{Lt}$ and vice versa $\mathrm{H} 0$ is accepted if Lt is greater than L0 can simply be stated as follows:

$\mathrm{H} 0=$ accepted if $\mathrm{L} 0>\mathrm{Lt}$, it means that the data is not normally distributed.

$\mathrm{Ha}=$ accepted if $\mathrm{LO}<\mathrm{Lt}$, it means that the data is normally distributed.

The results of the complete calculation of the normality test can be seen in table 2 below:

Table 2. Summary of Research Data Normality Test Results

\begin{tabular}{|c|c|c|c|c|}
\hline Variable & $\mathrm{n}$ & Lo & Lt & Conclusion \\
\hline $\mathrm{X} 1$ to $\mathrm{Y}$ & 44 & 0.102 & & Normal \\
\hline $\mathrm{X} 2$ to $\mathrm{Y}$ & 44 & 0.080 & & Normal \\
\hline $\mathrm{X} 3$ to $\mathrm{Y}$ & 44 & 0.070 & \multirow{2}{*}{0.155} & Normal \\
\hline $\mathrm{X} 1$ to $\mathrm{X} 3$ & 44 & 0.128 & & Normal \\
\hline $\mathrm{X} 2$ to $\mathrm{X} 3$ & 44 & 0.066 & & Normal \\
\hline
\end{tabular}

Information:

$\mathrm{n} \quad=$ number of samples

L0 $=$ L obesvasi value

$\mathrm{Lt}=\mathrm{L}$ table value

Based on the results of the calculation of the normality 
test of the research variables above, it was found that the value. The $\mathrm{L} 0$ obtained is smaller than the Lt value at the significance level $\alpha=0.05$. Thus, it can be concluded that all data groups in this study were taken from normally distributed populations so that they could continue to be used to test the research hypothesis.

\subsubsection{Data Homogeneity Test}

The homogeneity test was used to test whether the data on serviceability variables came from a homogeneous population of variance, flexibility, leg muscle explosive power, and self-confidence. Ha what is tested in this case is the data on the service ability $(\mathrm{Y})$ of West Sumatra sepaktakraw athletes on the variance of leg muscle explosive power (X1), flexibility (X2), confidence (X3), comes from a homogeneous population. The test criteria are $\mathrm{Ha}$ accepted when the value of $\mathrm{X} 2$ count obtained from the calculation $<\mathrm{X}$ 2table. The summary of the homogeneity test can be seen in table 3 .

Table 3. Homogeneity Test Results Variable serviceability (Y) on the variance of leg muscle explosive power (X1), flexibility (X2) and self-confidence (X3)

\begin{tabular}{|c|c|c|c|}
\hline Variable & X 2 count & $\begin{array}{c}\text { X 2 table } \\
\alpha=0.05\end{array}$ & Conclusion \\
\hline $\begin{array}{c}\text { Y over the variance } \\
\text { of X1 }\end{array}$ & 9.50 & 23.7 & Homogeneous \\
\hline $\begin{array}{c}\text { Y over the variance } \\
\text { of X2 }\end{array}$ & 17.19 & 35.20 & Homogeneous \\
\hline $\begin{array}{c}\text { Y over the variance } \\
\text { of X3 }\end{array}$ & 26.12 & 36.40 & Homogeneous \\
\hline $\begin{array}{c}\text { X3 over the variance } \\
\text { of X1 }\end{array}$ & 6.35 & 23.7 & Homogeneous \\
\hline $\begin{array}{c}\text { X3 over the variance } \\
\text { of X2 }\end{array}$ & 13.77 & 35.20 & Homogeneous \\
\hline
\end{tabular}

\subsubsection{Data Linearity Test}

The linearity test is a test that is carried out to see whether the variable data of explosive power of the limb muscles is respectively (X1), flexibility (X2), self-confidence (X3) tend to form a linear line to the variable service ability (Y) of West Sumatra sepaktakraw athletes. Ha what is tested in this case is the leg muscle explosive power (X1), flexibility (X2), self-confidence (X3), has a linear effect on the service ability (Y) of West Sumatra sepaktakraw athletes. The test criteria are Ha accepted if the sign value $>0.05$ probability value. The summary of the linearity test can be seen in table 4 below.

Table 4. Linearity Test Results Serviceability variable (Y) on the variance of leg muscle explosive power (X1), flexibility (X2), confidence (X3)

\begin{tabular}{|c|c|c|}
\hline Linearity Test & A value & Sig. \\
\hline X1 with $Y$ & & 0.724 \\
\cline { 1 - 1 } X2 with Y & \multirow{2}{*}{0.05} & 0.804 \\
\cline { 1 - 1 } X3 with Y & & 0.249 \\
\hline
\end{tabular}

Based on the table 4 above, which is searched using SPSS version 17.0, for X1 and Y data, the significance value $=0.582$ is greater than the probability value, namely $\alpha=0.05$. This explains that there is a significant linear relationship between the variable leg muscle explosive power (X1) and serviceability (Y). From the table above, for the $\mathrm{X} 2$ and $\mathrm{Y}$ data, the significance value $=0.136$ is greater than the probability value, namely $\alpha=0.05$. This explains that there is a significant linear relationship between the flexibility variable (X2) on serviceability $(\mathrm{Y})$. Furthermore, for the $\mathrm{X} 3$ and $\mathrm{Y}$ data, the significance value $=0.722$ is greater than the probability value, namely $\alpha=$ 0.05 .

\subsubsection{Hypothesis}

The framework for the empirical causal relationship between X1 and X2 against $\mathrm{Z}$ can be made through the structural equation as below:

$$
Y=\rho_{Z X_{1}} X_{1}+\rho Z_{X_{32}} X_{2}+\rho_{Z} \varepsilon_{1}
$$

To find the value of $\rho x \varepsilon 1$, residual variable is determined by the following formula:

$$
\begin{gathered}
=\mathbf{1}-\boldsymbol{R}_{\boldsymbol{X}_{32}}^{2} \\
=1-0.262 \\
=0.738
\end{gathered}
$$

So, the equation can be written as follows:

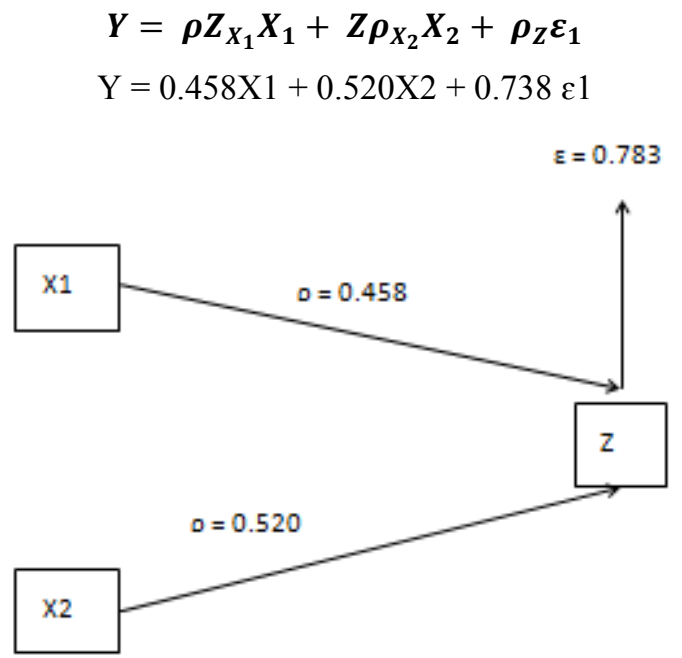

Figure 1. The framework for the empirical causal relationship between $\mathrm{X} 1$ and $\mathrm{X} 2$ against $\mathrm{Z}$

The framework for the empirical causal relationship between $\mathrm{X} 1$ and $\mathrm{X} 2$ against $\mathrm{X} 3$ shown in figure 1 can be made through the structural equation as below:

$$
Y=\rho_{X_{1}} X_{1}+\rho_{X_{2}} X_{2}+\rho_{X_{3}} X_{3}+\rho_{Y} \varepsilon_{1}
$$

To find the value of $\rho y \varepsilon 1$, residual variable is determined by the following formula:

$$
\begin{gathered}
=\mathbf{1}-\boldsymbol{R}_{\boldsymbol{X}_{32}}^{2} \\
=1-0.496 \\
=0.504
\end{gathered}
$$


So, the equation can be written as follows:

$$
\begin{gathered}
Y=\rho_{Y X_{1}} X_{1}+\rho_{Y X_{2}} X_{2}+\rho_{Y Z}+\rho_{Y} \varepsilon_{1} \\
Y=0.319 X 1+0.631 X 2+0.261 Z+0.619 \varepsilon 1
\end{gathered}
$$

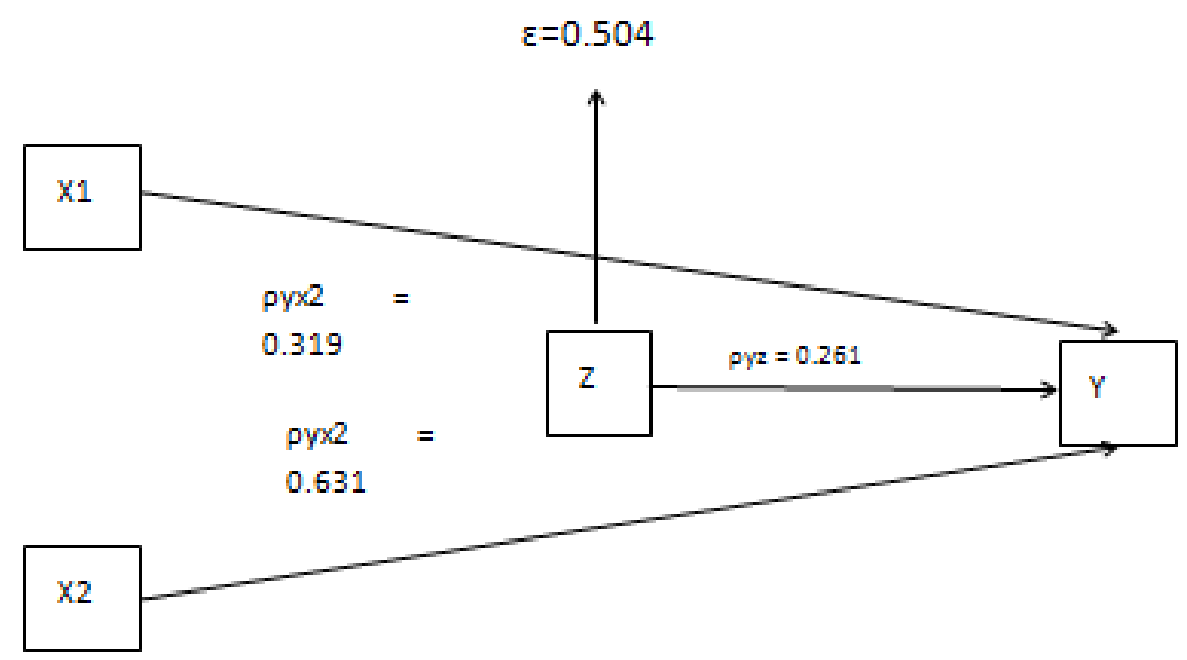

Figure 2. The framework for the empirical causal relationship between $\mathrm{X} 1$ and $\mathrm{X} 2$ against $\mathrm{X} 3$

\section{First Hypothesis}

Individual test conducted by $\mathrm{X} 1$ on $\mathrm{Y}$ found that the result of the path coefficient $\rho Y X 1=0.319$ at figure 2 . Based on the results of calculations carried out using the SPSS 23 program, the value of sig $=0.033$ is smaller than the value of $\alpha=0.05$, the value of $0.034<0.05$, so in this case $\mathrm{Ha}$ is accepted and $\mathrm{H} 0$ is rejected, which means that the coefficient of path analysis is significant. The magnitude of the influence of the vertical jump on serviceability is as follows:

$$
\begin{aligned}
& =\rho y \times 12 \times 100 \% \\
& =0.3192 \times 100 \% \\
& =10.1 \%
\end{aligned}
$$

So, based on the above, it can be concluded that leg muscle explosive power has a direct effect on serviceability by $10.1 \%$. However, the remaining $89.9 \%$ is influenced by other factors.

\section{Second Hypothesis}

Individual test conducted by $\mathrm{X} 2$ on $\mathrm{Y}$ found that the result of the path coefficient $\rho Y X 1=0.631$ at figure 2 . Based on the results of calculations carried out using the SPSS 23 program, the sig $=0.004$ value is smaller than the value of $\alpha=0.05$, the value is $0.004<0.05$, so in this case $\mathrm{Ha}$ is accepted and $\mathrm{HO}$ is rejected, which means the coefficient of path analysis is significant. The magnitude of the influence of flexibility on serviceability is as follows:

$$
\begin{aligned}
& =\rho y \times 12 \times 100 \% \\
& =0.6312 \times 100 \% \\
& =39.81 \%
\end{aligned}
$$

So, based on the above, it can be concluded that flexibility has a direct effect on serviceability amounting to $39.81 \%$. While the remaining $60.19 \%$ is influenced by other factors.

\section{Third Hypothesis}

Individual test conducted by $\mathrm{Z}$ on $\mathrm{Y}$ found that the path coefficient $\rho Y X 1=0.261$ at figure 2 . Based on the results of calculations carried out using the SPSS 23 program, the value of sig $=0.004$ is smaller than the value of $\alpha=0.05$, the value of $0.045<0.05$, so in this case $\mathrm{Ha}$ is accepted and $\mathrm{H} 0$ is rejected, which means the coefficient of path analysis is significant. The magnitude of the influence of confidence on serviceability is as follows:

$$
\begin{aligned}
& =\rho y \times 12 \times 100 \% \\
& =0.261 \times 100 \% \\
& =6.81 \%
\end{aligned}
$$

\begin{tabular}{|c|c|}
\hline The direct effect of $\mathrm{X} 1$ on $\mathrm{Y}$ ( $\rho \mathrm{yx} 1)$ & 0.319 \\
\hline Effect of X2 on Z ( $\rho z x 2)$ & 0.560 \\
\hline Direct effect of Z on Y ( $\rho z y)$ & 0.261 \\
\hline
\end{tabular}

So, based on the above, it can be concluded that self-confidence has a direct effect on serviceability amounting to $6.81 \%$. While the remaining $93.18 \%$ is influenced by other factors.

\section{Fourth Hypothesis}

Based on the results of the analysis test on the variable of explosive power on serviceability through confidence in serviceability, the following results were obtained:

Table 5. Direct influence 
Table 6. Indirect effect and contribution

\begin{tabular}{|c|c|}
\hline & $\rho Y X 1+(\rho \mathrm{zx} 2 \times \rho \mathrm{yz})$ \\
Indirect effect $=$ & $0.319+(0.560 \times 0.216)$ \\
& $0.319+0.120$ \\
& 0.439 \\
\hline \multirow{2}{*}{ Donation $=\rho_{y x 31}$} & $0.4392 \times 100 \%$ \\
& $0.192 \times 100 \%$ \\
& $19.2 \%$ \\
\hline
\end{tabular}

So, based on data analysis in table 6 , it can be said that the magnitude of the influence of explosive power through self-confidence on the service ability of sepaktakraw athletes is 0.192 or $19.2 \%$.

Fifth Hypothesis

Based on the results of the analysis test on flexibility variables on serviceability through self-confidence in sepaktakraw athletes, the following results were obtained:

Table 7. Direct influence

\begin{tabular}{|c|c|}
\hline The direct effect of X2 on Y ( $\mathrm{Xyx} 1)$ & 0.631 \\
\hline Effect of $\mathrm{X} 1$ on $\mathrm{Z}(\rho \mathrm{zx} 1)$ & 0.458 \\
\hline Direct effect of Z on Y ( $\rho y z)$ & 0.261 \\
\hline
\end{tabular}

Table 8. Indirect effect and amount of donation

\begin{tabular}{|c|c|}
\hline & $\rho y x 2+(\rho \mathrm{zx} 1 \times \rho \mathrm{xy})$ \\
Indirect effect $=$ & $0.631+(0.458 \times 0.261)$ \\
& $0.307+0.119$ \\
& 0.426 \\
\hline \multirow{2}{*}{ Donation $=\rho_{y x 31}$} & $0.4262 \times 100 \%$ \\
& $0.181 \times 100 \%$ \\
& $18.1 \%$ \\
\hline
\end{tabular}

So, based on data analysis in table 8 , it can be said that the magnitude of the influence of flexibility on serviceability through confidence in sepaktakraw athletes is 0.181 or $18.1 \%$.

\section{Sixth Hypothesis}

Based on the output table 9, the $r$ count value is $0.704>$ $\mathrm{r}$ table 0.320; and from the Annova in table 10, it is obtained $\mathrm{F}=11.86$ with probability $(\mathrm{sig})=0.000$, because the sig value $<\alpha=0.05$ then the decision is Ho is rejected and $\mathrm{Ha}$ is accepted. It can be concluded that together with the variable explosive power, flexibility and confidence have an effect on serviceability. The path equation of the variable explosive power, flexibility and confidence affects serviceability (X1, X2 and $\mathrm{Z}$ to $\mathrm{Y}$ ) using the formula:

$$
Y=\rho_{Y X 1} X_{1}+\rho_{Y X 2} X_{2}+\rho_{Y Z} Z+\rho_{Y} \varepsilon_{1}
$$

Where $\rho y \varepsilon 1=1-\mathrm{R} 2 \mathrm{YX} 123=1-0.496=0.504$

Thus, the equation paths $\mathrm{X} 1, \mathrm{X} 2$ and $\mathrm{Z}$ to $\mathrm{Y}$

$$
\mathrm{Y}=0.319 \mathrm{X} 1+0.631 \mathrm{X} 2+0.261 \mathrm{Z}+0.5041 \varepsilon
$$

The magnitude of the $\mathrm{R}$ square figure is 0.496 . This figure shows that the significant influence of the variable explosive power, flexibility and confidence on serviceability is:

$$
\begin{aligned}
\mathrm{KD} & =\mathrm{r} 2 \times 100 \% \\
& =0.496 \times 100 \% \\
& =49.6 \%
\end{aligned}
$$

The influence of the variable explosive power, flexibility and self-confidence on the serviceability is $49.6 \%$, while the remaining $50.4 \%$ is influenced by other factors.

Table 9. Model Summary

\begin{tabular}{|c|c|c|c|c|}
\hline Model & R & R Square & Adjusted R Square & Std. Error of the Estimate \\
\hline 1 & $.704 \mathrm{a}$ & .496 & .454 & 5.19559 \\
\hline
\end{tabular}

a. Predictors: (Constant), Self-Confidence, Flexibility, Explosive Power

Table 10. ANOVA

\begin{tabular}{|c|c|c|c|c|c|c|}
\hline \multicolumn{2}{|c|}{ Model } & Sum of Squares & df & Mean Square & F \\
\hline \multirow{3}{*}{1} & Regression & 956,112 & 3 & 318,704 & 11,806 \\
\cline { 2 - 6 } & Residual & 971,788 & 36 & 26,994 & $.000 \mathrm{~b}$ \\
\cline { 2 - 7 } & Total & 1927,900 & 39 & & \\
\hline
\end{tabular}

a. Dependent Variable: Serviceability

b. Predictors: (Constant), Confidence, Flexibility, explosive power 


\subsection{Discussion}

Sepaktakraw athletes must possess basic technical skills and abilities and special techniques. The basic techniques that must be possessed are kicking (soccer, sila, badek, prying and tread), thigh, chest, shoulder to shoulder and head. Specific techniques are serve, reserve, pass, smash and block. The start of football or commonly referred to as service is the beginning of the start of the sepaktakraw game. The first football is carried out by tekong towards the opponent's field, which is one way to get points[7]. Service consists of 2, namely: Service Down and top service. Lower service is done by standing with one foot in a circle and the other leg at the back of the body for the start and the part of the inner leg hitting the ball. Unlike the above service, top service is done using the instep and service with the sole of the foot.

To get the serve well, physical ability is required. As for the physical conditions required in the implementation of the serve are explosive power and flexibility. Explosive power is one of the important components in carrying out the sepaktakraw service. Because this bio motor component, namely the explosive power, determines how fast a person can hit, how far he can throw, how high he jumps, how fast he can run and so on[8]. Therefore, this component is very important for a takraw player to get a good ball speed when serving. Explosive power physiologically based on muscle contraction is categorized as elastic strength, which is the type of strength that is needed, in order to overcome resistance firmly and quickly[9]. Another component of the physical condition that plays a role in service delivery is flexibility. Flexibility is the ability to perform joint movements through a wide range of motion[10]. Flexibility gives the beauty of movement during servicing. With flexibility, the movement will be more aligned and able to maximize the height of the leg when serving. Therefore, flexibility is a basic component that must be improved for sports that require a wide range of joint movements. Sepaktakraw is a sport that demands a wide range of motion in carrying out the basic techniques that are carried out. The benefits of flexibility for sepaktakraw athletes are increasing the ability to rotate, increasing support, increasing recovery, and reducing injuries[11]. Other than that,, Mobility and the dynamics of a person's movement are influenced by flexibility. In sepaktakraw sports, this ability serves to avoid injury to athletes[12].

Another important aspect that also plays a role is self-confidence. Strong self-confidence has been proven to contribute to the success of the service. In essence, self-confidence is closely related to the philosophy of self-fulfillment (self-fulfilling prophecy) and self-confidence (self-efficacy). Athletes with good self-confidence believe that they are able to perform well as expected[13]. It is added that self-confidence is an attitude or feeling of confidence in one's own abilities so that the person feels comfortable doing activities and does not feel anxious in his actions. Believing this can be seen in my man, such as being able to feel free to do what he likes and be responsible for his actions, in addition to feeling warm and polite in interacting with people and having the drive to achieve[13]. Another opinion adds that self-confidence consists of aspects, namely: a) Ability to solve problems, b) Responsible for the actions taken, c) Has the ability to get along well., D) and has the ability to accept criticism from others[14]

The results showed that self-confidence had an influence on the ability to serve sepeaktakraw. This can be explained that self-confidence provides extraordinary support for the individual to work better in every activity. On the other hand, good explosive power has an impact on confidence in acting[15]. Previous research has shown that there was a positive relationship between explosive power and self-confidence[16]. This is explained by Weinberg and Gould that self-confidence has a positive impact on the following things, namely emotion, concentration, goals, efforts and strategies[17]. Good emotions possessed by individuals or athletes tend to show that the athlete has good self-confidence. Confidence can be increased in various ways including focusing on the game, acting confidently, responding confidently, thinking confidently, using images and goal mapping, optimizing physical conditioning and training, and conditioning preparation[18]. The concentration of an athlete becomes easier if an athlete is able to grow self-confidence in himself. Whereas target is likely to aim at challenging targets so that it will encourage him to work better. For the business aspect, individuals do not easily give up on achieving the targets that have been planned and tend to keep trying their best to achieve them. The most recent impact has been on strategy.

\section{Conclusions}

The results showed that the leg muscle explosive power, flexibility and confidence had an influence on the service ability in the sepaktakraw game. The leg muscle explosive power has a direct effect on serviceability by $10.1 \%$, flexibility has a direct effect on serviceability amounting to $39.81 \%$, and self-confidence has a direct effect on serviceability amounting to $6.81 \%$. The results also show indirect effect of the variable on serviceability. The influence of explosive power through self-confidence on the service ability of sepaktakraw athletes is $19.2 \%$. Influence of flexibility on serviceability through confidence in sepaktakraw athletes is $18.1 \%$, while the influence of the variable explosive power, flexibility and self-confidence had an effect on serviceability amounting to $49.6 \%$. While the remaining $50.4 \%$ is influenced by other factors. This influence is also given by other factors outside the variables under study. Based on these results, it is suggested that a training proportion be provided based on the variables that have been proven to have direct and 
indirect effects.

\section{Acknowledgements}

Thanks are conveyed to Ristekdikti which has provided assistance in the implementation of this research so that this research can run well.

\section{REFERENCES}

[1] H. Forsman, M. Blomqvist, K. Davids, J. Liukkonen, and N. Konttinen, "Identifying technical, physiological, tactical and psychological characteristics that contribute to career progression in soccer," Int. J. Sport. Sci. Coach., vol. 11, no. 4, pp. 505-513, 2016, doi: 10.1177/1747954116655051.

[2] F. J. Lawless and H. W. Grobbelaar, "Sport psychological skills profile of track and field athletes and comparisons between successful and less successful track athletes. / Sportsielkundige vaardigheidsprofiel van baan- en veldatlete en vergelykings tussen suksesvolle en minder suksesvolle b," South African J. Res. Sport. Phys. Educ. Recreat., vol. 37, no. 3, pp. 123-142, 2015, [Online]. Available: http://search.ebscohost.com/login.aspx?direct=t rue $\& \mathrm{db}=\mathrm{s} 3 \mathrm{~h} \& \mathrm{AN}=111215749 \&$ lang=pt-br\&site=ehost-liv

[3] S. Zeivots, "Triggers of emotional highs in experiential learning," J. Adventure Educ. Outdoor Learn., vol. 00, no. 00, pp. 1-14, 2018, doi: 10.1080/14729679.2018.1443482.

[4] M. Atefifard et al., "Special Issue," 2016, doi: 10.1016/S0040-1951(06)00452-5.

[5] M. N. Jawis, R. Singh, H. J. Singh, and M. N. Yassin, "Anthropometric and physiological profiles of sepak takraw players," Br. J. Sports Med., vol. 39, no. 11, pp. 825-829, 2005, doi: 10.1136/bjsm.2004.016915.
[6] A. Mohamad Razali, A. Saidon, and K. S. Pathmanathan, "Visual Perception of Kuda and Sila Service," Movement, Heal. Exerc., vol. 1, no. 1, pp. 26-37, 2012, doi: 10.15282/mohe.v1i0.7.

[7] M. Suhud, Sepaktrakraw. Jakarta: Balai Pustaka, 1990

[8] A. Agus, "Manajemen Kebugaran teori dan praktek." Padang: SUKABINA Press, 2013.

[9] J. Tangkudung, Kepelatihan Olahraga "Pembinaan Prestasi Olahraga. Jakarta: Cerdas jaya, 2006.

[10] J. Tangkudung, Kepelatihan Olahraga. Jakarta: Cerdas Jaya, 2012.

[11] R. Engel, Dasar-Dasar Sepak Takraw. Bandung: Pakar Raya, 2010.

[12] D. P. Irianto, Panduan Praktis Berolahraga. Yogyakarta: Andi Offset, 2004

[13] M. . Setiadarma, Dasar-dasar Psikologi Olah Raga. Jakarta: Pustaka Sinar Harapan, 2000.

[14] A. Kumara, "Studi Validitas dan Reliabilitas The Test of Self-Confidance," Universitas Gajah Mada, 1987.

[15] O. Candra, M. Asmawi, and J. Tangkudung, "the Effect Leg Muscle Explosive Power, Flexibility, Hand Eye Coordination and Confidence of Skill Lay Up Shoot Basketball," Jipes - J. Indones. Phys. Educ. Sport, vol. 3, no. 2, pp. 162-192, 2017, doi: 10.21009/jipes.032.13.

[16] Jufrianis et al., "Model of physical condition of leg muscle explosive power, nutrition status and confidence towards skill smash sepaktakraw," in Proceedings of the International Conference on Industrial Engineering and Operations Management, 2019, no. July, pp. 2062-2069.

[17] R. S. Weinberg and D. Gould, Foundations of sport and exercise psychology (fourth edition), Fourth. U.S.A: Human Kinetics, 2007.

[18] R. Weinberg and G. Daniel, Foundations of Sport and Exercise Psychology 7th Ed., 7th ed. United States of America: Human Kinestetics, 2019. 